Szymon Drzyżdżyk

Uniwersytet Papieski Jana Pawła II w Krakowie

Marek Gilski

Uniwersytet Papieski Jana Pawła II w Krakowie

\title{
Sobory pierwszego tysiąclecia o rozeznaniu
}

\section{Wprowadzenie}

Rozeznanie woli Bożej od zawsze sprawiało ludziom sporo trudności. Czasem, jak poświadcza Biblia, ludzie nie podejmowali się rozeznawania jakiejś trudnej sprawy, lecz decydowali się czekać na osobę posłaną od Boga, która rozstrzygnie, co zrobić. O takiej sytuacji wspomina 1 Księga Machabejska. Chodziło o problem zbezczeszczonego ołtarza. Ołtarz rozebrano, ale kamienie złożono w jednym miejscu na tak długo, aż ukaże się prorok i wyda co do nich rozporządzenie (1 Mch 4,46).

Dzieje Apostolskie poświadczają, że także chrześcijaństwo od początku stawało przed trudnymi problemami, które trzeba było rozeznać. Bardzo szybko pojawiło się pytanie, czy wszyscy, którzy stają się chrześcijanami, muszą przyjąć wpierw judaizm. Jezus nic nie mówił na ten temat, nie było więc prostej odpowiedzi na tak postawiony problem. Apostołowie rozeznali tę kwestię na tzw. Soborze Jerozolimskim. 
Decyzje soborowe były w przekonaniu apostołów rozstrzygnięciem nie tylko ojców, ale przede wszystkim Ducha Świętego, na co wskazują słowa: „Postanowiliśmy Duch Święty i my” (Dz 15,28). W ten sposób drogą do rozeznawania stały się sobory; miało ono zatem charakter wspólnotowy, co pozwalało na unikanie subiektywizmu.

W pierwszym tysiącleciu odbyło się osiem soborów. Wszystkie zostały zwołane w sytuacji, gdy Kościół stawał przed trudnymi problema$\mathrm{mi}$, które groziły rozłamem. Sobory z jednej strony rozeznawały problemy i podejmowały konkretne decyzje, $\mathrm{z}$ drugiej natomiast dawały pewne wskazówki, jak rozwiązywać trudne sytuacje w przyszłości.

Celem obecnego artykułu jest analiza dokumentów soborów pierwszego tysiąclecia z perspektywy rozeznania. Nie chodzi jednak o analizowanie akt soborowych, lecz dokumentów finalnych, czyli definicji wiary, kanonów i anatematyzmów. Tak postawiony cel sprowadza się do szeregu szczegółowych pytań: Co to jest rozeznanie? Jaki jest jego cel? W oparciu o jakie kryteria się dokonuje? Jakich kwestii dotyczy?

W dokumentach soborowych nie znajdziemy ani definicji rozeznania, ani teoretycznego traktatu o rozeznaniu. Mimo to kanony poszczególnych soborów nie tylko są przykładem rozeznawania w praktyce, ale też zawierają postulaty badania trudnych spraw, dając wskazówki, w jaki sposób ma się ono dokonywać. Z kwestią rozeznania wiążą się przywoływane w dokumentach soborowych następujące pojęcia greckie:

- $\delta о \kappa \iota \mu \alpha \sigma i \alpha^{1}$,

- $\delta о \kappa \iota \mu \alpha \zeta \omega^{2}$,

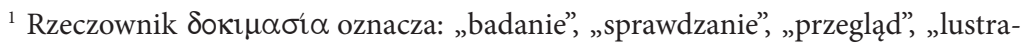
cję”, „próbę”, „doświadczenie”. W starożytnych tekstach pojawia się w kontekście sprawdzania kwalifikacji kandydatów do pełnienia urzędów. Por. Z. Abramowiczówna (red.), Słownik grecko-polski, t. I, Warszawa 1958, s. 593. W Atenach większość urzędów była wyznaczana losem. Aby nie zdawać się całkowicie na los czy ślepy traf, Ateńczycy ustanowili instytucję dokimazji, która polegała na badaniu zarówno kwalifikacji fachowych, jak i politycznych, moralnych oraz intelektualnych wybranych losem kandydatów. Por. R. Turasiewicz, Wstęp, [w:] Demostenes, Wybór mów, przeł. i oprac. R. Turasiewicz, Wrocław 2005, s. XX-XXI.

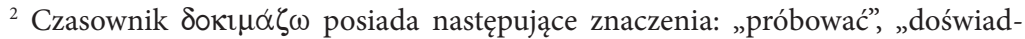
czać”, „wybierać”, „poddać próbie, badaniu”, „uznać”, „zatwierdzić”, „sprawdzić warunki kandydata na urząd". Por. Z. Abramowiczówna (red.), Słownik grecko-polski, t. I, s. 593. 
- $\dot{\varepsilon} \xi \varepsilon \tau \alpha \dot{\alpha} \zeta \omega^{3}$

- $\dot{\varepsilon} \xi \dot{\varepsilon} \tau \alpha \sigma \iota \varsigma^{4}$,

- $\kappa \rho i ́ l \varsigma^{5}$,

oraz łacińskie:

- discerno $^{6}$,

- discretio $^{7}$

- discretor ${ }^{8}$,

- examinatio

- probatio $^{10}$

- perscrutor $^{11}$.

3 Czasownik ' $\xi \varepsilon \tau \alpha \zeta \zeta \omega$ w zależności od kontekstu może oznaczać: „wybadać”, „wypróbować, „rozpatrzyć”, „robić przegląd”, „zrewidować”, „wyliczyć”, „wypytać dokładnie”, „ocenić”, „oszacować”, „porównać”, „doświadczać”. Por. Z. Abramowiczówna (red.), Słownik grecko-polski, t. II, Warszawa 1960, s. 178.

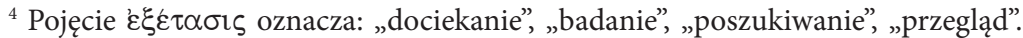
Por. Z. Abramowiczówna (red.), Słownik grecko-polski, t. II, s. 178.

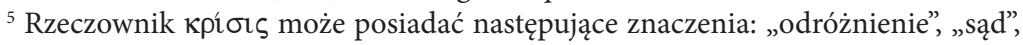
„wybór”, „rozstrzygnięcie”, „badanie”, „próba”, „wynik”. Por. Z. Abramowiczówna (red.), Słownik grecko-polski, t. II, s. 716-717.

6 Termin discerno oznacza: „rozdzielić”, „oddzielić”, „odłączyć”, „wybrać”, „rozróżniać”, „rozsądzić”, „osądzić”, „rozstrzygać”, „rozpoznać”, „rozeznać”, „poznać”, „zbadać”, „wyznaczyć”, „ustalić”. Por. M. Plezia (red.), Słownik łacińsko-polski, t. II, Warszawa 1998, s. 183.

${ }^{7}$ Rzeczownik discretio posiada następujące znaczenia: „podział”, „rozdział”, „rozdzielenie”, „granica”, „odległość”, „rozróżnienie”, „umiejętność rozróżniania”, „rozsądzenie”, „sąd”, „różnica”, „odmienność”. Por. M. Plezia (red.), Słownik łacińsko-polski, t. II, s. 188.

${ }^{8}$ Pojęcie discretor oznacza: „ten, kto odróżnia, rozróżnia, rozsądza”. Por. M. Plezia (red.), Słownik łacińsko-polski, t. II, s. 189.

${ }^{9}$ Rzeczownik examinatio pochodzi od czasownika examinare i oznacza: „ważenie”, „badanie”, „rozważanie”, „dochodzenie”. Por. M. Plezia (red.), Słownik łacińsko-polski, t. II, s. 384 .

${ }^{10}$ Pochodzący od czasownika probare termin probatio posiada następujące znaczenia: „próba”, „ocena”, „badanie”, „przegląd”, „uznanie”, „akceptacja”, „dowód (prawdy)”, „argument”. Por. M. Plezia (red.), Słownik łacińsko-polski, t. IV, Warszawa 1999, s. 298.

${ }^{11}$ Czasownik perscrutor może oznaczać: „przeszukiwać”, „przetrząsać”, „śledzić”, „tropić”, „badać”, „zgłębiać”. Por. M. Plezia (red.), Słownik łacińsko-polski, t. IV, s. 126. 
Dokumenty soborowe nie zawierają żadnego spójnego wykładu na temat rozeznania. Wydaje się, że samo to pojęcie jest rozumiane w sensie potocznym, dlatego też nie znajdziemy na kartach dokumentów soborowych żadnych wzmianek na temat celowości rozeznania. Mamy tam raczej do czynienia z praktyką rozeznawania.

Cztery spośród ośmiu soborów pierwszego tysiąclecia podjęły problem rozeznawania trudnych problemów: Sobór Nicejski I (325), Sobór Chalcedoński (451), Sobór Konstantynopolitański II (553), Sobór Konstantynopolitański IV (869-870). Owe cztery sobory wyznaczają też strukturę artykułu.

\section{Sobór Nicejski I}

Dokumenty soborowe ${ }^{12}$ przywołują zarówno rzeczownik $\delta$ okı $\mu \alpha-$

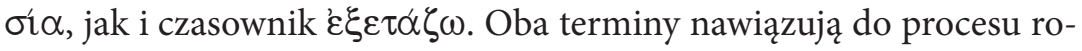
zeznawania, który może przyjmować różną formę.

Kanony soborowe, dokonując rozstrzygnięcia trudnych spraw, niejednokrotnie wskazują na kryteria, w oparciu o które to czynią. Sobór Nicejski I wymienił następujące punkty odniesienia dla procesu rozeznania. Chodzi o: pismo apostolskie ( $\tau \grave{\alpha} \dot{\alpha} \pi \circ \sigma \tau 0 \lambda \iota \kappa o ̀ v$

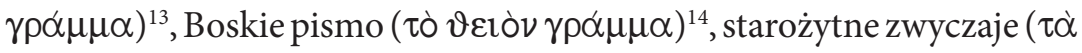

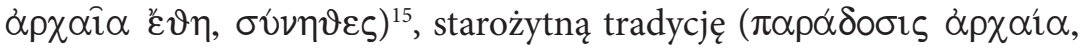

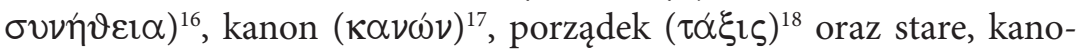

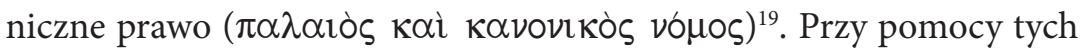
kryteriów kanony dokonują wielu rozstrzygnięć. Mamy więc nawią-

12 J.D. Mansi, Sacrorum Conciliorum Nova et Amplissima Collectio, vol. II, Graz 1960, s. 665-678.

${ }^{13}$ Kanon II.

${ }^{14}$ Kanon XVII.

${ }^{15}$ Kanon VI.

${ }^{16}$ Kanon VII.

${ }^{17}$ Kanon II, XV, XVIII.

${ }^{18}$ Kanon XVIII.

${ }^{19}$ Kanon XIII. 
zania do Biblii, tradycji, zwyczajów, porządku i prawa jako ważnych punktów odniesienia przy podejmowaniu decyzji. Chociaż Sobór nie definiuje pojęć: „zwyczaju”, „tradycji”, „kanonu”, „prawa” czy „porządku", to jednak dla wyeksponowania ich znaczenia dodaje przymiotniki:

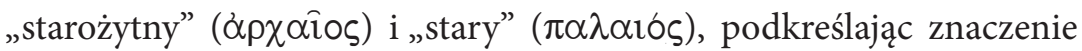
czasu przy ocenie sytuacji. Ojcowie soborowi dają wyraz przekonaniu, że mogą pojawiać się także nowe zwyczaje i że należy je oceniać z perspektywy kanonów. Jeśli są sprzeczne z nimi, trzeba ich zabronićc ${ }^{20}$.

Kanon II Soboru Nicejskiego I podejmuje zagadnienie odstępu czasowego między chrztem a przyjęciem do stanu duchownego. Krytycznie ocenia praktykę ustanawiania prezbiterami lub biskupami nowo ochrzczonych. Przytaczając jako argument 1 List do Tymoteusza, zabraniający ustanawiania neofity biskupem, aby nie wbił się w pychę i nie wpadł w diabelskie potępienie (1 Tm 3,6-7), nakazuje ochrzczonemu odbycie dłuższej próby ( ciem święceń. Sobór nie daje żadnych szczegółowych wskazówek na temat czasu tej próby i sposobu weryfikowania kandydata do święceń. Chodzi o zagwarantowanie dłuższego okresu po chrzcie, który pozwoli na lepsze rozeznanie osoby kandydata. Chociaż w analizowanym kanonie pojawia się argumentacja biblijna, to wspomina on o tym, że w historii miały miejsce przypadki udzielania święceń neofitom, ale działo się tak wskutek bądź konieczności, bądź nalegania ludzi. Było to jednak sprzeczne z kanonami. Dlatego sobór zaleca, aby na przyszłość nie postępowano w ten sposób.

Ojcowie soborowi, świadomi, że relacje międzyludzkie mogą być naznaczone postawami sprzecznymi z Ewangelią, zalecają, aby w każdej prowincji dwa razy w roku zwoływano synody ${ }^{21}$. Ich celem jest ro-

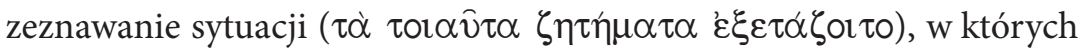
ktoś został wyłączony ze wspólnoty przez biskupa. Mogło bowiem do tego dojść w przekonaniu Ojców soborowych nie z racji obiektywnych,

${ }^{20}$ Por. M. Gilski, M. Cholewa, Język soborów pierwszego tysiąclecia, Kraków 2018, s. $36-38$.

${ }^{21}$ Kanon V. 
lecz z powodu małoduszności biskupa lub kierowania się przez niego uczuciem niechęci ${ }^{22}$. Kanon V Soboru Nicejskiego I zaleca zatem wspólne i stosunkowo częste (dwa razy w roku) rozeznawanie okoliczności wykluczania ze wspólnoty. Dwukrotnie pada w tym kontekście termin „wszyscy”, wskazujący, że chodzi o wszystkich biskupów prowincji. W proces rozeznawania mają zatem być zaangażowani wszyscy biskupi bez wyjątku. Jego efektem może być złagodzenie kary wyłączenia ze wspólnoty.

Kanon XII Soboru Nicejskiego I stawia przed biskupem zadanie rozeznawania autentyczności nawrócenia. Chodzi o sytuację „chrześcijan, początkowo gorliwych, którzy jednak odeszli, by robić karierę w wojsku"23. Mają oni pokutować najpierw ze słuchającymi, a potem z klęczącymi. Ci z nich, którzy wejdą na drogę autentycznego nawrócenia, wyrażoną przez bojaźń, łzy, cierpliwość i dobre uczynki, mogą uzyskać skrócenie czasu pokuty i po okresie przebywania trzy lata ze słuchającymi mogą zostać dopuszczeni do uczestnictwa w modlitwie $\mathrm{z}$ wiernymi. Rola biskupa polega na rozeznawaniu zarówno szczerości decyzji ${ }^{24}$, jak i autentyzmu zewnętrznych wyrazów zmiany sposobu myślenia

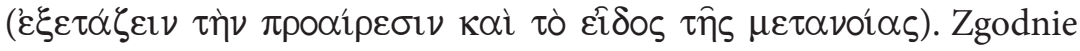
z kanonem biskup może skrócić czas odbywania pokuty. Nie ma jednak wzmianek, aby mógł go wydłużyć. Od rozeznania biskupa zależy zatem, czy okaże on pobłażliwość, czy też zaleci odbycie pełnej pokuty.

Moment śmierci jest chwilą dopuszczania do komunii z Kościołem. Kanon XIII podaje jako regułę, że nikomu nie wolno odmawiać wiaty-

${ }^{22}$ Jak zauważa H. Pietras [Sobór Nicejski (325), Kraków 2013, s. 149]: „Instytucja systematycznych synodów przedstawiona tu jest jako odwoławcza. Oczywiście synody odbywały się już wcześniej, tu jednak chodzi prawodawcom o uniknięcie sytuacji, w której synod mógłby być celowo odwlekany, by metropolita nie musiał się z nim konfrontować. Przy arbitralności pewnych wyroków było bowiem możliwe skrzywdzenie kogoś lub też niesłuszne rehabilitowanie w innym miejscu".

${ }^{23}$ H. Pietras, Sobór Nicejski (325), s. 157.

${ }^{24}$ Grecki termin $\pi \rho \circ \alpha i ́ p \varepsilon \sigma ı \varsigma$ oznacza zarówno: zamiar, postanowienie, cel, plan działania, jak i samo postępowanie. Por. Z. Abramowiczówna (red.), Słownik greckopolski, t. III, Warszawa 1962, s. 624. 
ku. Mamy do czynienia z grzesznikiem, który podjął pokutę albo też jej nie rozpoczął. Jego życie jest zagrożone, a on sam prosi o dopuszczenie go do komunii z Kościołem. Ojcowie soborowi „nawiązują tu do tradycji nakazującej udzielanie komunii - w każdym słowa znaczeniu, czyli i Eucharystii, i pojednania ze wspólnotą - pokutnikowi w niebezpieczeństwie śmierci”25. Rola biskupa ma polegać na rozeznaniu, którego charakter nie jest jednak szczegółowo doprecyzowany. To jednak

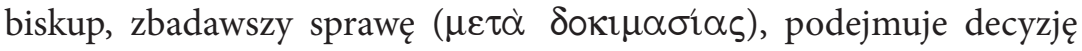
o dopuszczeniu do wspólnoty.

Praktycznym przykładem rozeznania, nawiązującym do współcześnie dyskutowanych kwestii małżeństwa, jest kanon VIII tego soboru. Tekst brzmi następująco:

W sprawie tych, którzy nazywają samych siebie katharoi [to znaczy „czystymi”], święty i wielki sobór postanowił, że jeżeli chcą powrócić do powszechnego i apostolskiego Kościoła, muszą otrzymać nałożenie rąk, a będą mogli pozostać w gronie duchownych. Konieczne jest jednak, przede wszystkim, aby oni przyobiecali na piśmie, że zgadzają się i będą posłuszni nauczaniu Kościoła powszechnego. Następnie, że pozostaną we wspólnocie z tymi, którzy dwa razy zawarli małżeństwo, oraz z tymi, którzy upadli w czasie prześladowań, a którym został wyznaczony czas na odbycie pokuty i stosowna pora, aby uznali swe posłuszeństwo we wszystkim nauczaniu powszechnego i apostolskiego Kościoła.

Jak zauważa H. Pietras: „Widzimy, że ojcowie soborowi stoją na stanowisku, że każdemu podejmującemu pokutę należy podać rękę i przyjąć na powrót do Kościoła. Nota o tych, którzy dwa razy zawarli małżeństwo, nie precyzuje, czy chodzi tylko o wdowców/wdowy, czy o ludzi rozwiedzionych. Moim zdaniem ten brak precyzacji jest celowy i chodzi i o jednych, i o drugich (...) aż do IX wieku nie było ślubów kościelnych i Kościół uznawał śluby cywilne. W państwie zaś były rozwody i były przewidziane kary dla kogoś, kto ośmieliłby się ważność rozwodów i drugich związków podawać w wątpliwość. Począwszy od

${ }^{25}$ H. Pietras, Sobór Nicejski (325), s. 157. 
IV wieku, ukształtowały się w Kościele dwie tradycje. Na Wschodzie uznano, że należy postępować zgodnie z zapisem tego kanonu i dopuszczać drugie małżeństwo nie tylko wdowców i wdów, ale także rozwodników, oczywiście po pokucie, która zgodnie z kanonami pokutnymi św. Bazylego Wielkiego mogła trwać nawet kilkanaście lat. Na Zachodzie coraz częściej zawężono zakres kanonu i nie godzono się na komunię rozwodników żyjących w nowych związkach. Praktyka wschodnia w żadnym wypadku nie była i nie jest lekceważeniem Ewangelii, tylko praktyką pokutną ustaloną przez Kościół, któremu Chrystus pozostawił władzę odpuszczania grzechów.

Jak widzimy, propozycja papieża Franciszka, by w duszpasterskim działaniu indywidualnie rozważyć każdy przypadek i szukać sposobu na to, by rozwiedzeni i żyjący w nowych związkach mogli powrócić do życia sakramentalnego, nie jest nowinką podważającą dogmaty, ale prostym nawiązaniem do starożytnej praktyki pokutnej. Tak jak w starożytnym Kościele sprzeciwiali się temu różni katarzy, tak i teraz słychać głośne oburzenie współczesnych „katarów”, tak przywiązanych do własnych upodobań, że niezdolnych do szukania większego dobra. Cytowany kanon Soboru Powszechnego w Nicei ustala, że katarzy niechcący się zgodzić na obecność w Kościele pokutujących grzeszników nie mogą w nim być duchownymi”26.

\section{Sobór Chalcedoński}

Dokumenty soborowe ${ }^{27}$ przywołują zarówno rzeczownik $\delta$ okı $\mu \alpha-$

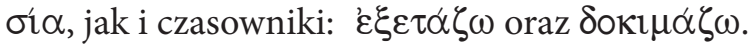

Kanon XIX Soboru Chalcedońskiego powtarza znane z Soboru Nicejskiego zalecenie odbywania synodów w każdej prowincji dwa razy $\mathrm{w}$ roku. To przypomnienie związane jest $\mathrm{z}$ faktem nieprzestrzegania

${ }^{26}$ H. Pietras, Herezje, Kraków 2019, s. 138-140.

${ }^{27}$ Interesujące nas kanony znajdują się w: E. Schwarz (ed.), Concilium Universale Chalcedonense, vol. I, 2, 2, Epistularum Collectio B, Actiones III-VII, Berolini-Lipsiae 1933, s. 158[354]-163[359]. 
przepisów sformułowanych w Nicei. Jak zaznaczają Ojcowie soborowi, $\mathrm{z}$ racji nieodbywania się nakazanych synodów liczne sprawy kościelne, które wymagają reformy, są zaniedbywane. Stąd nakazują, aby we

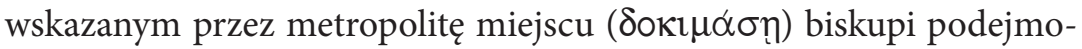
wali palące problemy Kościoła. Mamy w tym kontekście do czynienia z jakąś formą rozeznawania także miejsca, gdzie ma się odbywać synod. Leży to w gestii metropolity.

Kanon XXI poleca natomiast rozeznawanie sytuacji, gdy ktoś - czy to świecki, czy duchowny - wnosi oskarżenie przeciw biskupowi lub

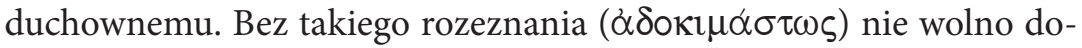
puścić do wniesienia oskarżenia ${ }^{28}$. Kanon doprecyzowuje, że chodzi

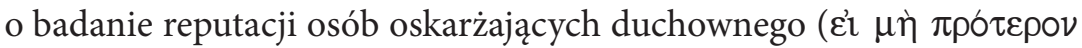

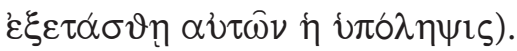

Sobór Chalcedoński stawia przed biskupami zadanie rozeznawania przed udzieleniem święceń diakonisom. Kanony soborowe nie tylko określają minimalny wiek kandydatek (40 lat), ale też nakazują biskupo-

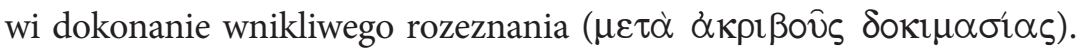
Kanon XV wspomina w tym kontekście o karze wyłączenia ze społeczności wiernych diakonis, które wyszły za mąż. Wydaje się zatem, że biskup powinien rozeznać stan duchowy przyszłej diakonisy oraz jej zdolność do życia w samotności.

Rola biskupa polega również na rozeznawaniu sytuacji ( $\mu \varepsilon \tau \dot{\alpha}$ $\delta о \kappa \imath \mu \alpha \sigma i \alpha \varsigma) ~ l u d z i$ biednych i potrzebujących i podejmowaniu ewentualnej decyzji o wydaniu im „listów pokoju”. Ma to miejsce w sytuacji, gdy owi biedni udają się w podró $\dot{z}^{29}$. Wydaje się, że mamy w tym kontekście do czynienia z wyłącznie chrześcijańskim fenomenem, jakim jest poddawanie badaniu ludzi potrzebujących pomocy. Nie są to osoby aspirujące o jakiś kościelny urząd ani o dopuszczenie do udziału w Eucharystii, ale ubiegające się o list, który uwiarygodni jego posiadacza w środowisku ludzi nieznających go osobiście ${ }^{30}$.

\footnotetext{
${ }^{28}$ Kanon XXI.

${ }^{29}$ Kanon XI.

${ }^{30}$ M. Gilski, M. Cholewa, Język soborów pierwszego tysiąclecia, s. 86.
} 


\section{Sobór Konstantynopolitański II}

Chociaż na dorobek Soboru Konstantynopolitańskiego II składa się zarówno wyrok przeciwko Trzem rozdziałom, jak i anatematyzmy, to jednak tematyka rozeznania pojawia się jedynie w zachowanym przede wszystkim w języku łacińskim wyroku ${ }^{31}$. Na kartach tego dokumentu znajdziemy następujące terminy: examinatio, perscrutari oraz кpíıı. W przeciwieństwie do wcześniejszych soborów, które koncentrowały się na dawaniu wskazówek na temat tego, kto powinien rozeznawać i co powinno być przedmiotem rozeznawania, Ojcowie zgromadzeni w Konstantynopolu deklarują, że podjęli proces badania Trzech rozdziałów (fecimus examinationis trium capitulorum) i rozpatrzyli sprawę Teodora z Mopsuestii. Jego pisma były przedmiotem ich lektury i zawarte w nich bluźnierstwa zostały potępione.

W związku z sygnalizowanymi wątpliwościami, czy jest dozwolone potępienie osoby już nieżyjącej, Ojcowie soborowi zdecydowali się zbadać również tę kwestię (de hoc perscrutari). Proces rozeznania dokonał się w oparciu o trzy kryteria: Bożych sędziów (Dei iudicatorum), nauczanie apostołów (apostolicarum pronuntiationum) oraz tradycje Ojców (paternarum traditionum). Wyrok przeciwko Trzem rozdziałom przytacza fragmenty z Ewangelii św. Jana („Kto wierzy w Niego, nie podlega potępieniu, a kto nie wierzy, już został potępiony, bo nie uwierzył w imię Jednorodzonego Syna Bożego") ${ }^{32}$ i z Listu św. Pawła do Galatów („Ale gdybyśmy nawet my lub anioł z nieba głosił wam Ewangelię różną od tej, którą wam ogłosiliśmy - niech będzie przeklęty! Już to przedtem powiedzieliśmy, a teraz jeszcze mówię: Gdyby wam kto głosił Ewangelię różną od tej, którą [od nas] otrzymaliście - niech bę-

${ }^{31}$ Zachowane fragmenty greckie wyroku znajdują się w: J. Straub (ed.), Concilium Universale Constantinopolitanum sub Iustiniano habitum, vol. I, Concilii Actiones VIII, Appendices Graecae - Indices, Berolini 1971, s. 239-240. Teksty łacińskie cytujemy za: A. Baron, H. Pietras (red.), Dokumenty soborów powszechnych. Tekst grecki, łaciński i polski, t. I, Kraków 2001, s. 262-282.

${ }^{32} \mathrm{~J} 3,18$. 
dzie przeklęty") 33, aby następnie zapytać, czy słowa te dotyczą jedynie żywych. Pytanie to ma charakter retoryczny, gdyż Ojcowie soborowi podkreślają czas teraźniejszy obecny w słowach Jezusa. Brak wiary oznacza bowiem faktyczne potępienie. Zawężanie go tylko do żywych jest w przekonaniu Ojców przejawem ignorancji albo udawaniem nieświadomości w tym zakresie.

Po przytoczeniu argumentów biblijnych wyrok przeciwko Trzem rozdziałom przywołuje także teksty św. Cyryla Aleksandryjskiego, które expressis verbis wspominają o unikaniu ludzi uwikłanych w grzechy, niezależnie do tego, czy żyją, czy też nie (evitandi sunt illi, qui tam pessimis culpis detinentur, sive in vivis sunt, sive non). Ojcowie soborowi odwołują się także do św. Augustyna (bez przytoczenia konkretnych tekstów) oraz do tradycji Kościołów w Afryce i w Rzymie, które praktykowały pośmiertną ekskomunikę.

Przedmiotem badań soboru były również pisma Ibasa (ad examinationem proposita). Ojcom soborowym wystarczyła lektura jego listu do Marina Persa, aby dostrzec zawartą w nim bezbożność (impietas). Przy tej okazji pojawia sie także wzmianka o wcześniejszych oskarżeniach kierowanych pod adresem Ibasa, w związku z którymi patriarchowie Konstantynopola zlecili Focjuszowi, biskupowi Tyru, badania jego pism (causae examinationem delegaverunt). Wyrok przeciwko Trzem rozdziałom przytacza również kierowany przez Ibasa pod adresem Soboru Efeskiego zarzut, że odrzucił on naukę Nestoriusza bez

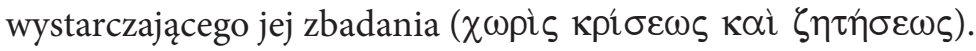

\section{Sobór Konstantynopolitański IV}

Już we wstępnym orzeczeniu (Terminus sanctae et universalis synodi) Ojcowie soborowi podkreślają, że cesarz dzięki swojemu doskonałemu rozeznaniu i rozpoznaniu tego, co jest dobre i pożyteczne (ad perfectam discretionem et distinctionem eius quod bonum esse constat et expedit), zwołał sobór. Oni sami natomiast $\mathrm{z}$ wielką starannością zba-

\footnotetext{
${ }^{33} \mathrm{Ga} 1,8-9$.
} 
dali sprawę Focjusza (cum multo scrutinio et probatione). W szczegółowych rozstrzygnięciach odwołują się nie tylko do Pisma Świętego, ale i do kanonów wcześniejszych soborów. Podkreślają znaczenie zarówno słowa Bożego, które pozwala rozeznać myśli (cogitationum discretor) ${ }^{34}$, jak i kanonów, dzięki którym możemy odróżnić to, co lepsze, od tego, co gorsze (quod discernitur melius a peiori).

W kanonie IX (w języku greckim) ${ }^{35}$ Ojcowie soborowi przypominają biblijny zakaz wydawania osądów bez uprzedniego zbadania spra-

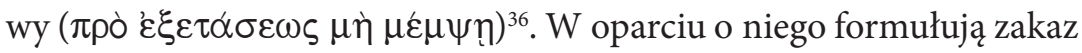
zrywania wspólnoty z własnym patriarchą przez kogokolwiek (świecki, mnich, duchowny), bez uprzedniego wnikliwego rozeznania sprawy

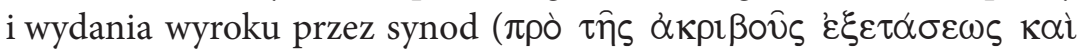

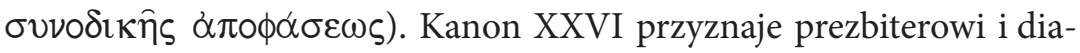
konowi, zdjętym z urzędu przez biskupa, możliwość odwołania się do metropolity, którego z kolei zobowiązuje, aby wraz z biskupami rozeznał całą sprawę (faciat examen).

Sobór powtarza przepisy Soboru Nicejskiego I o nieustanawianiu biskupami neofitów. Poszerza jednak tę perspektywę, zakazując wyświęcania na biskupa nawet kogoś, kto był kapłanem bardzo krótko. Podkreśla konieczność dłuższego czasu próby i przejścia wszyst-

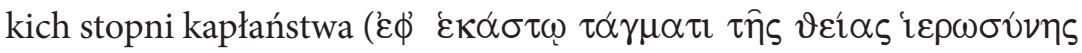

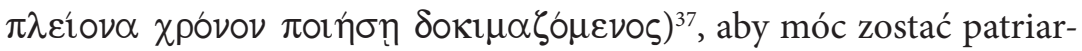
chą. Kontekst wskazuje, że w ten sposób Ojcowie soborowi bronią Kościoła przed naciskami władzy cesarskiej, która chciałaby ingerować w obsadzanie stanowiska patriarchy. Sobór ma świadomość, że do takiej sprzecznej z kanonami sytuacji może jednak dojść, dlatego stwierdza, że gdyby ktoś otrzymał godność patriarchy bez wcześniejszego

${ }^{34}$ Por. Hbr 4,12.

${ }^{35}$ Chodzi o kanon X w wersji łacińskiej. Dokumenty tego soboru cytujemy za: A. Baron, H. Pietras (red.), Dokumenty soborów powszechnych. Tekst grecki, łaciński i polski, t. II, Kraków 2002, s. 28-104. Na stronach parzystych znajdują się teksty w języku greckim i łacińskim, a na nieparzystych ich polskie tłumaczenia.

${ }^{36}$ Syr 11,7 .

${ }^{37}$ Kanon V. 
pełnienia funkcji lektora (rok), subdiakona (dwa lata), diakona (3 lata) i prezbitera (4 lata), zostanie usunięty z urzędu ( $\alpha \pi \circ \delta \circ \kappa \iota \mu \alpha \sigma \vartheta \eta ं \omega$

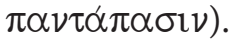

\section{Wnioski}

Przeprowadzone analizy dokumentów soborów pierwszego tysiąclecia w kontekście kwestii rozeznania pozwalają sformułować następujące wnioski.

1. W oficjalnych dokumentach Kościoła nie ma definicji rozeznania. Wydaje się, że chodzi o coś oczywistego, czego nie trzeba dookreślać. Na kartach dokumentów soborowych nie znajdziemy spójnego traktatu o rozeznaniu. Ojcowie soborowi rozeznają różne sytuacje i nie tylko dają rozstrzygnięcia, ale też prezentują wskazania dla Kościołów lokalnych.

2. Dokumenty soborowe wspominają przede wszystkim o biskupach jako osobach, których rolą jest rozeznawanie. Chodzi zarówno o poszczególnych biskupów, jak i o wspólnotę biskupów, która zbierając się dwa razy do roku na synodach, ma rozeznawać stające przed Kościołem wyzwania i rozwiązywać trudne kwestie. Dzięki synodalności proces rozeznawania nie ma charakteru czysto subiektywnego. Kościół wypracował zatem mechanizm rozeznawania (synod), ale nie podał gotowych rozstrzygnięć.

3. Ojcowie soborowi, świadomi, że w pewne sytuacje może wdać się czynnik osobisty, który może zaowocować brakiem obiektywizmu biskupa, dopuszczają możliwość apelacji od decyzji biskupa do metropolity lub synodu, a od decyzji metropolity nawet do patriarchy Konstantynopola.

4. Ojcowie soborowi w swoich rozstrzygnięciach najczęściej odwołują się do Biblii, kanonów, tradycji poszczególnych Kościołów oraz do autorytetu świętych. Zdarza się jednak, że bez podania punktu odniesienia dyskwalifikują jakiś tekst jako bezbożny. 
5. Ważnym elementem w procesie rozeznania jest czas. Stąd też Ojcowie soborowi nie tylko wymagają określonego wieku do podjęcia posług w Kościele, ale i odpowiednio długiego czasu, który pozwoli lepiej poznać ludzkie predyspozycje.

6. Rozeznanie autentyzmu nawrócenia leży w gestii biskupa. To on może okazać miłosierdzie. Rozeznanie co do słuszności kar czy wykluczeń z Kościoła należy do kompetencji synodu.

7. Celem procesu rozeznania jest przede wszystkim dobro poszczególnych chrześcijan.

\section{Summary}

The aim of this article is to analyze the documents of the first millennium councils in terms of discernment. The subject of the analyses is not the files of the councils, but the final documents, i.e. the definitions of faith, canons and anathema's. The issue of discernment is related to

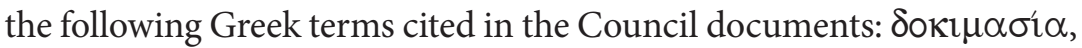

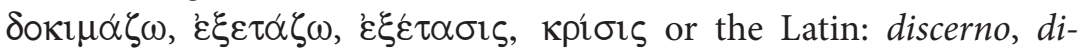
scretio, discretor, examinatio, probatio, perscrutor.

The analyses, which was carried out, allowed to formulate the following conclusions.

1. There is no definition of discernment in the official documents of the Church. It seems that discernment is something obvious, which does not need to be specified. A coherent treaty of discernment cannot be found on the pages of the Council documents. The Council Fathers discern various situations and not only give solutions, but also present indications for local Churches.

2. The conciliar documents primarily mention the bishops as persons whose task is to discern. This concerns both individual bishops and the community of bishops who, meeting twice a year in synods, is 
to discern the challenges facing the Church and solve difficult issues. As a result of the synods, the discernment process is not purely subjective. The church therefore developed a mechanism for discernment (the synod), but it did not provide ready solutions.

3. The Council Fathers, aware that in some situations a personal factor may be present which may result in the bishop's lack of objectivity, they allow the appeal of the bishop's decision to the metropolitan or synod, and even the patriarch of Constantinople.

4. The Council Fathers in their decisions most often refer to the Bible, canons, traditions of particular Churches and to the authority of saints. It happens, however, that without providing a reference point, they disqualify some text as impious.

5. Time is an important element in the process of discernment. Therefore, the Council Fathers not only require a certain age before entering into ministry in the Church, but also a reasonably long time of practicing the ministry, which will allow better understanding of the human predisposition.

6. The recognition of the authenticity of conversion rests with the bishop. He can show mercy. Discernment as to the correctness of penalties or exclusions from the Church lies within the competence of the synod.

7. The aim of the discernment process is first and foremost the good of individual Christians.

Keywords: terminology of discernment, the first millennium councils 


\section{Bibliografia}

Abramowiczówna Z. (red.), Słownik grecko-polski, t. I, Warszawa 1958.

Abramowiczówna Z. (red.), Słownik grecko-polski, t. II, Warszawa 1960.

Abramowiczówna Z. (red.), Słownik grecko-polski, t. III, Warszawa 1962.

Baron A., Pietras H. (red.), Dokumenty soborów powszechnych. Tekst grecki, łaciński i polski, t. I, Kraków 2001.

Baron A., Pietras H. (red.), Dokumenty soborów powszechnych. Tekst grecki, łaciński i polski, t. II, Kraków 2002.

Gilski M., Cholewa M., Język soborów pierwszego tysiąclecia, Kraków 2018.

Mansi J.D., Sacrorum Conciliorum Nova et Amplissima Collectio, vol. II, Graz 1960.

Pietras H., Sobór Nicejski (325), Kraków 2013.

Pietras H., Herezje, Kraków 2019.

Plezia M. (red.), Słownik łacińsko-polski, t. II, Warszawa 1998.

Plezia M. (red.), Słownik łacińsko-polski, t. IV, Warszawa 1999.

Schwarz E. (ed.), Concilium Universale Chalcedonense, vol. I, Epistularum Collectio B, Actiones III-VII, Berolini-Lipsiae 1933.

Straub J. (ed.), Concilium Universale Constantinopolitanum sub Iustiniano habitum, vol. I, Concilii Actiones VIII, Appendices Graecae - Indices, Berolini 1971.

Turasiewicz R., Wstęp, w: Demostenes, Wybór mów, przeł. i oprac. R. Turasiewicz, Wrocław 2005, s. V-CLIV. 